\title{
El modo lírico en el cuadro de Vincent Van Gogh Botines con lazos y en el poema de Olga Orozco "Botines con lazos, de Vincent Van Gogh"1
}

\section{The Lyrical Mode in Vincent Van Gogh's Picture Ankle Boots with Ties and in Olga Orozco's Poem "Ankle Boots with ties, by Vincent Van Gogh"}

\author{
doi) doi.org/10.48162/rev.54.003 \\ María Troiano de Echegaray \\ Facultad de Filosofía y Letras, Universidad Nacional de Cuyo \\ matmariatroiano@gmail.com
}

\section{Resumen}

Según Kurt Spang las distintas artes — pintura, música, literatura, etc.además de las características propias de cada una, presentan elementos esenciales comunes a todas ellas. Ello permite demostrar que las artes se relacionan entre sí de manera original y fecunda, tal como lo hacen las diferentes literaturas nacionales. En este sentido, Spang propone una serie de componentes o elementos esenciales a tener en cuenta para definir a qué modo pertenecen las distintas obras. En este caso nos detenemos en el modo lírico para demostrar que el cuadro Botines con lazos, de Vincent van

${ }^{1}$ En la base de este artículo se halla el curso sobre géneros literarios que el profesor Kurt Spang dictó en el marco de la Maestría de Literatura Argentina Contemporánea de la Facultad de Filosofía y Letras (UNCuyo) en 2005. 
Gogh, pertenece a la lírica, al igual que la poesía "Botines con lazos, de Vincent van Gogh," de Olga Orozco.

Palabras clave: literatura; pintura; Van Gogh; Olga Orozco.

\begin{abstract}
According to Kurt Spang, the different arts - painting, music, literature, etc. - in addition to their individual characteristics, present essential elements common to all of them. This makes it possible to demonstrate that the arts are related to each other in an original and fruitful way, just as the different national literatures are. In this sense, Spang proposes a series of components or essential elements that should be considered to define the mode to which different works belong. In this case we focus on the lyric mode to show that the painting Ankle boots with Ties, by Vincent van Gogh, belongs to lyric, as does the poem "Ankle boots with ties, by Vincent van Gogh", by Olga Orozco.
\end{abstract}

Keywords: literature; painting; Van Gogh; Olga Orozco.

El estudio de la naturaleza del arte y la reflexión sobre ello viene de muy antiguo, pero es en la segunda mitad del siglo XX cuando aumenta ese interés y se profundiza sobre un aspecto en particular: las relaciones de las artes entre sí. Y será la Literatura Comparada la que se ocupará de analizar los modos efectivos de encuentro de las distintas expresiones artísticas, intentando explicar el porqué de ciertas elecciones y de los encuentros, felices y no, concretados en obras de arte, reconociendo de esta manera que las distintas manifestaciones artísticas mantienen espontáneamente entre sí fecundas relaciones, tal y como lo hacen las distintas literaturas.

La afirmación de Simónides de Ceos de que "la poesía es pintura que habla y la pintura poesía muda", origen del tópico literario horaciano de ut pictura poesis, describe la relación entre figura y palabra como si fuera, usando un término de nuestro tiempo, una especie de interfaz (Pantini, 2002: 219): 
una poesía plástica, una música rica en claroscuros, un cuadro verboso. Es decir, se trata del encuentro entre dos formas de arte que actúa como un dispositivo capaz de transformar las señales generadas por una de ellas en señales comprensibles para la otra; un encuentro que se convierte en una zona de comunicación o acción de un sistema sobre otro. Como explica Vicente-Yagüe Jara,

Lessing apunta que las conexiones existentes entre la pintura y la literatura han de ser enfocadas desde una misma tradición temática, aunque con la especificidad del sistema de signos propio de cada código artístico. Así pues, afirma que la literatura y el arte pueden conseguir efectos significativos comunes, sin obviar que los signos empleados son diferentes (2013: 38).

Kurt Spang sugiere "hacer lo que une" frente a la multiplicación agobiante -reconoce él- de definiciones del arte y de la literatura. Para ello, propone reflexionar sobre los aspectos comunes que poseen las artes $y$, con ellos, los criterios que permiten definir la literatura como una de las artes, más allá de la diversidad histórica y fáctica. Su propuesta define las artes a partir de la capacidad y obligación que ellas tienen de "hacer transparente el ser a través de los trascendentales" (Spang, 2005: 30). Para ello, es necesario determinar cuáles son aquellos elementos esenciales, constitutivos de la actividad cultural, que sirven para una definición de arte y que, repitiéndose en cada arte-y por ende también en la literaturaforman un conjunto de constantes fundamentales que se pueden apreciar en todas las artes y en cada una de sus obras. Guiándonos por ellos, comentaremos las dos obras de arte propuestas en el título, la pintura "Botines con lazos", de Vincent Van-Gogh y el poema "Botines con lazos, de Vincent Van Gogh", de Olga Orozco. Se trata de dos obras de arte de 
diferentes ámbitos, la pintura y la literatura, en relación con su pertenencia a un "modo" particular, el lírico. A partir de esto, intentaremos confirmar esta intuición de que las dos responden a los componentes específicos.

Los "componentes" siempre presentes, que hay que desglosar en el análisis de la obra de arte, son básicamente seis, están estrechamente relacionados aunque no jerarquizados y Spang los organiza en tres grupos: conceptuales, formales $y$ funcionales. El componente conceptual es el fondo/forma y responde a la intencionalidad del autor de materializar la transmisión de un mensaje -fondo- que proviene de la preocupación emanada de la cosmovisión del artista, lo que implica, por su parte, haber tomado decisiones sobre la Verdad y la Bondad, es decir, sobre los transcendentales. Es la fuerza, la energía que "informa", que le da forma a la obra de arte.

El componente formal (o material) abarca tres aspectos: el sustrato, el modo y el género; ellos son los que suministran modelos preestablecidos, aunque flexibles, para la realización de la obra. El sustrato es el material que utiliza cada artista para plasmar el tema. Permite la materialización de la obra de arte convirtiéndola en un objeto sensorialmente perceptible. Es el puente, entre la inspiración creadora y su posterior realización y ulterior interpretación; es el vehículo y soporte de la realidad plasmada en la obra. La obra de arte se sitúa entre lo material y lo espiritual; entre el tema y la idea y la materia. La obra no se agota en la transmisión del mensaje sino que permanece también la idea con su configuración; ella tiene un valor propio y queda disponible para otras interpretaciones ya que es importante no solo lo que dice, sino también cómo lo dice. El modo o modalidad son para Spang la triada tradicional de lírica, épica, dramática; y reserva la voz género para las 
divisiones de estos modos (novela, sinfonía, retrato, bajo relieve, etc.). Resulta interesante el punto de vista antropológico que sigue Spang para la definición de modo, partiendo del concepto de R. Alvira cuando dice que los seres humanos actuamos en la vida de manera lírica, dramática o épicamente (2001: 11-16). Esto implica que toda actividad humana, toda actividad cultural pertenece a un modo. Propone la relación de la temporalidad como criterio decisivo distintivo, puesto que el hombre es en el tiempo, y es el empleo del tiempo lo que repercute sobre la actividad humana. En la lírica, predomina la dimensión temporal del pasado, aunque eso no es todo y a ello nos referiremos más adelante. En tanto, digamos que los modos son una especie de cauce creativo, una actitud que canaliza la inspiración hacia moldes particulares que reciben su forma definitiva en el género, los modos son la condición de la posibilidad del surgimiento de los géneros.

El componente funcional comprende dos aspectos: la comunicación y la ficcionalización. Toda obra de arte comunica y esto significa que hay un emisor que codifica y un receptor que decodifica, cumpliendo así la función social del arte, aun cuando por lo común, la comunicación artística se realiza in absentis, diferida. La literatura es el arte que más manifiestamente comunica, en primer lugar, por su substrato, el lenguaje, instrumento de comunicación por antonomasia, el más apto para evocar, para describir una conflictualidad, etc. En segundo lugar, por la ficcionalidad del contenido $y$, en tercer lugar, por el valor estético del lenguaje.

La ficcionalización literaria es el componente más complejo y está presente desde el inicio. No es un fin en sí mismo sino que sirve para superar lo puramente fáctico o fenoménico, porque 
la obra literaria no es imitación servil del mundo existente sino que está destinada a abrir la mirada hacia lo esencial más esencial del hombre y del mundo, es otra forma de la verdad. La ficción auténtica es el medio artístico para superar la contingencia, el continuo fluir y la continua diversidad del mundo para convertirlo en forma fija, inamovible (concepto que nos recuerda la poética pirandelliana); inmoviliza el tiempo y el espacio para permitir una mirada más allá de las apariencias, sobre el ser de la realidad. La ficcionalización se realiza ya sea con la mayor objetivación posible, parecido máximo con la naturaleza, o bien con la mayor subjetividad, alejándose de la realidad en mayor o menor medida; entre ambos extremos existe una extensa gama de posibilidades intermedias.

La teoría de Spang resulta muy interesante para los estudios comparatistas porque evidentemente permite cruzar los límites - ¿naturales?-que cada arte tiene y enriquece en gran manera el análisis, la interpretación y el goce de cada obra de arte. Y agrega Spang: "y ayudará sin duda a encontrar y aplicar criterios más sólidos que ayuden a distinguir más objetivamente el arte de la impostura" (2001: 29). Toda su teoría busca brindar un nuevo enfoque de los géneros literarios. Se interesa particularmente en este tema considerando que la teoría de los géneros o genología "es la disciplina más longeva y más compleja de la teoría de la literatura" (Spang, 2001: 165) y, a la vez, uno de los aspectos menos trabajados aunque más fértil a los fines de la definición más completa y acertada de arte y de literatura.

Es nuestro propósito realizar un análisis aproximativo de dos obras de arte de diferente ámbito, la pintura y la literatura, en relación con su pertenencia a un "modo" particular, el lírico, y 
confirmar esta intuición de que las obras mencionadas en el título responden a los componentes específicos. La comprobación procederá en base al listado de los componentes genéricos sugeridos por Kurt Spang. Nos pareció muy interesante la idea de una teoría abarcadora de todas las artes que permita definir una obra de cualquier ámbito artístico y establecer su pertenencia a determinado modo y género.

Es innegable la realidad de esta pertenencia a lo lírico, a lo dramático, a lo épico o a lo narrativo de obras pictóricas y musicales, por ejemplo. Un ejemplo es el conocido mural de Pietro Lorenzetti ubicado en la Basílica Inferior de la Basílica de San Francisco, en Asís, Madonna con il Bambino tra San Giovanni evangelista e San Francesco, llamado también La Madonna dei Tramonti, obra de admirable delicadeza y finísimo arte. El fresco representa a cuatro personajes de los cuales dos están dialogando. En el centro de la pintura, se desarrolla una escena de vida cotidiana: la Virgen María está hablando con el Niño Jesús y la gestualidad manifiesta el diálogo en acto. El diálogo, aparentemente mudo pero explicitado en los gestos, nos vuelve copartícipes, nos involucra. Un maravilloso Bambino, cómodamente sentado en los brazos de la mamá, reclama su atención con los dedos de la mano y quiere hablar, según la expresión interrogativa del rostro. La madre lo escucha atenta. Las dos figuras a los lados son San Juan Evangelista y San Francisco y el Niño pregunta, para no confundirse al elegir: "dime mamá, ¿a quién debo dirigirme primero?" Y la madre le contesta señalando con el pulgar de la mano derecha a San francisco, casi como si le dijera "estamos en su casa, ¿no?" Atentos y silenciosos, aguardan los dos santos. Con solo ese gesto, el arte deviene repentinamente vida. 


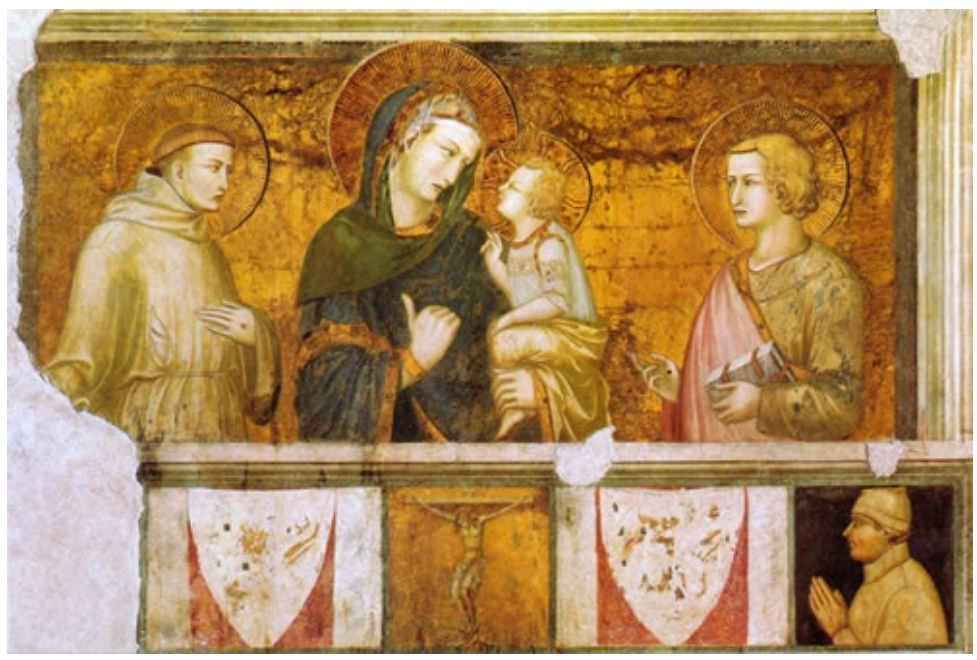

Ni aun al más lego de los observadores puede escapársele el dramatismo de la pintura, que desarrolla un animado diálogo entre los personajes representados: las miradas y los gestos "hablan", preguntan y responden. Pero si bien la pertenencia a un género es clara y evidente en algunas obras, no lo es en otras. Ello exige una teorización que sistematice datos constantes y variantes que permitan posteriormente su aplicación. Siguiendo la teoría formulada por Spang, intentamos analizar desde ese punto de vista el cuadro Botines con lazos de Van Gogh y el poema "Botines con lazos, de Vincent Van Gogh" de Olga Orozco.

Para ello realizaremos en primer lugar una síntesis de los contenidos teóricos que sustentan los conceptos de modo y género, especialmente. Aplicaremos luego el análisis de los componentes en las obras de arte elegidas. 


\section{La obra de arte: Unidad, Verdad, Bondad y Belleza}

En la base de esta teoría sobre los géneros, están los conceptos fundamentales de natura, cultura y arte, definidos desde cierto enfoque y punto de vista particular. Nos parece necesario referirnos a ellos para sustentar este trabajo de aproximación a las dos obras de arte propuestas para el análisis.

Si partimos de la diferenciación fundamental entre "natura" y "cultura", diremos que "natura" es aquello que nos es dado y que funciona y se desarrolla sin la intervención del hombre, mientras que "cultura" es todo lo producido por el hombre, tanto la actividad de producción como el resultado de ella. De acuerdo con esto, el "arte" resulta así una de las posibles actividades humanas dentro del ámbito de la cultura. Para definir "cultura" se recurre a los trascendentales platónicos: Unidad, Verdad, Bondad y Belleza. Tanto las actividades humanas como los productos de ellas realizan y reúnen en sí lo uno, lo verdadero, lo bello y lo bueno, los cuales se manifiestan siempre juntos y en proporciones diversas.

La Unidad se manifiesta en las obras de arte logradas: es la perfección unificadora de sus partes y en ella se refleja la unidad del ser. Tenemos una capacidad innata para concebir la unidad porque concebimos el universo, el mundo y la vida, que son unidades. A pesar de que nuestra percepción de la unidad es como una cantidad de diversidades, detrás de ellas captamos la unidad, agrupamos en conjuntos. Es una necesidad para poder abarcar la realidad. Es más, si miramos el lenguaje, cada palabra en sí misma es una unidad.

Para la expresión y captación de la Verdad es necesaria la lengua, que no es solamente una estructura autorreferencial 
sino que debe ser capaz de formular la verdad sobre los fenómenos del ser y del ente. El concepto de la "verdad" es sencillo cuando coincide la conceptualización con el objeto observado: "las cosas como son". Pero se vuelve complejo cuando la lengua no es suficiente ni capaz de expresar, de referirnos esa verdad. Remite a algo externo a ella. Sin la lengua, no podemos pensar ni concebir las cosas. El concepto es difícil cuando buscamos llegar a la verdad de las sensaciones, de los sentimientos. La queja de los poetas es siempre por la dificultad para poder llegar al meollo de la cuestión. Pero todas las verdades que podemos conocer son parciales. Nunca sabremos todo sobre todas las cosas y sobre nosotros mismos. De todos modos, todas esas parcialidades no son prueba suficiente para decir que no haya verdad, que no exista la verdad. Conocer la verdad es una necesidad natural del hombre. La pintura Botines con lazos de Van Gogh expresa sin dudas una verdad que es parcial, seguramente, limitada, fragmentada, pero una verdad, que se capta a nivel sensorial y emocional y que cuesta describir en lenguaje verbal.

En la consideración de la Bondad, se debe tener en cuenta una doble perspectiva: por un lado, hacer bien, lo que responde a la aspiración a la perfección que anima el quehacer humano y de modo particular al artista, "perfeccionista inmisericorde"; por el otro lado, hacer el bien, que corresponde a la perspectiva ética que rige todo quehacer humano y por lo tanto también el artístico.

En cuanto a la Belleza, se la considera una especie de coronación, de conjugación de los cuatro trascendentales. Platón dice que "si es bueno, es bello". La belleza puede ser el brillo y el esplendor de la verdad y de la bondad. Hay que diferenciar entre belleza natural, espontánea, que nace en la 
Naturaleza sin intervención del hombre y la belleza "cultural", aquella creada por el hombre, tanto en el arte cuanto en otras actividades productivas humanas (el diseño de automóviles, muebles, ropa, etc.). Es la belleza a la que llamamos "funcional". Para descubrirla, sea en la naturaleza o en los productos del hombre, debemos pensarla como una idea impregnada en una materia con una forma determinada. Es decir, la forma es la materialización de un tema y un contenido. Teniendo en cuenta esto, algunos criterios para decir que algo es "bello" serían el "splendor forma" de Santo Tomás, la "limpieza", la armonía, la proporción, en definitiva, la configuración adecuada de un fondo que de por sí debe obedecer a los mandatos de la Verdad y la Bondad.

\section{Las artes y la obra de arte}

Los trascendentales se realizan más densa e intensamente en el arte. Las artes son, por antonomasia, el ámbito de la cultura ideal para plasmar la actividad del hombre con una mirada profundizadora sobre la realidad, conocerla y conocerse a sí mismo. Spang parte de una premisa fundamental, según la cual la obra de arte siempre es expresión de algo; la creación está guiada por el deseo y la intención de transmitir una idea, un mensaje, y al construirlo el artista tiene en cuenta los transcendentales (2005: 13-14).

En su proceso de creación, el artista busca y trata de realizar la forma adecuada al fondo, a la idea que está rigiendo su acto creador. Como "puente" entre la inspiración creadora y su materialización, está el substrato que, como ya dijimos, es vehículo y soporte, es la materia en que se manifiesta la obra de arte; sonidos, ritmo, colores, líneas; palabras, etc. 


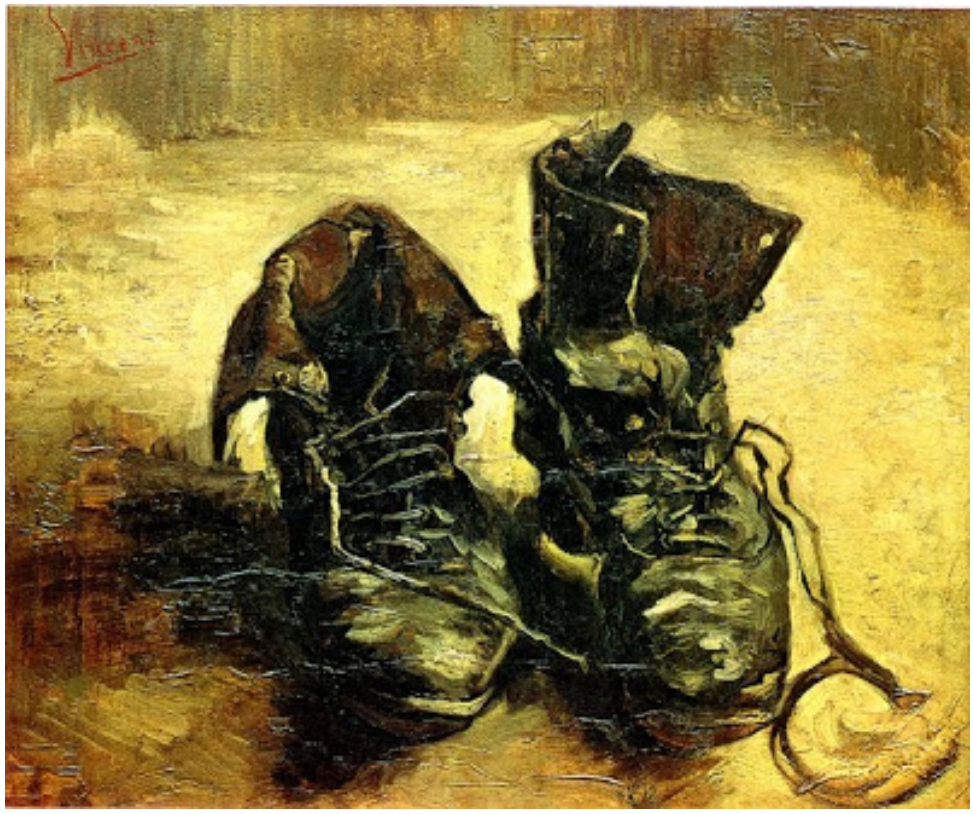

El cuadro Botines con lazos² de Van Gogh y el poema "'Botines con lazos' de Vincent Van Gogh", de Olga Orozco, constituyen una muestra visible del funcionamiento de estos componentes.

Olga Orozco actúa como un receptor creativo. A continuación, reproducimos el poema, que fue publicado en el volumen $L a$ noche a la deriva en 1983:

${ }^{2}$ Botines con lazos. París, segundo semestre de 1886 . Óleo sobre tela, $37,5 \times 45 \mathrm{~cm}$. Amsterdam, Rijksmuseum Vincent van Gogh, Fondation Vincent van Gogh. Datos obtenidos en: Rainer Metzger - Ingo F. Walther. VINCENT VAN GOGH. 1853-1890. Taschen, Cologne, 2001. 


\section{“BOTINES CON LAZOS” DE VINCENT VAN GOGH}

¿Son dos extraños fósiles,

emisarios sombríos de una fauna sepultada en un bosque de carbón,

Que vienen a reclamar un óbolo de luz para sus muertos?

¿Son ídolos de piedra,

cascotes desprendidos del obraje de los más tristes sueños?

¿O sin moldes de hierro

para fraguar los pasos a imagen del martirio y a semejanza de la penitencia?

Son tus viejos botines, infortunado Vincent,

hechos a la medida de un abismo interior, como las ortopedias del exilio;

dos lonjas de tormento curtidas por el betún de la pobreza, embalsamadas por lloviznas agrias,

con unos lazos sueltos que solamente trenzan el desamparo con la soledad,

pero con duros contrafuertes para que sea exiguo el juego del destino,

para que te acorrale contra el muro la ronda de los cuervos.

Pero son tus botines, perfectos en su género de asilo, modelos para atar a cada ráfaga de alucinada travesía, fieles como tu silla, tus ojos y tu Biblia.

Aferrados a ti como zarpas fatales desde las plantas hasta los tobillos,

desde Groot Zundert hasta la posada del infierno final, es inútil que quieran sepultar tus raíces en una casa hundida en el rescoldo,

en el barro bruñido, el brillo de las velas y el íntimo calor de las patatas, 
porque una y otra vez tropiezan con el filo de la mutilación, porque una y otra vez los aspira hacia arriba la tromba que no entienden:

tu fuga de evadido como un vértigo azul, como un cráter de fuego.

Botines de trinchera, inermes en la batalla del vendaval y el alma:

han girado contigo en todas las vorágines del cielo

y han caído en la trampa de tu hoguera oculta bajo el incendio de los campos

sin encontrar jamás una salida,

por más que pisoteen esas flores fanáticas que zumban como abejorros amarillos,

esos soles furiosos que atruenan contra tu oreja, tan distante,

perdida como un pálido rehén entre los torbellinos de otro mundo.

Botines de tribunal, a tientas en la noche del patíbulo, sin otro resplandor que unos pobres destellos arrancados al pedernal de la locura, entre los que hay un pájaro abatido en medio de su vuelo: el extraño, remoto anuncio blanco de una negra sentencia. Resuenan dando tumbos de ataúd al subir la escalera, vacilan junto al lecho donde se precipitan vidrios de increíbles visiones,

trizado por una bala el árido universo,

y dejan caer a lentas sacudidas el balance de polvo tormentoso adherido a sus suelas.

Ahora husmean la manta de hiedra que recubre tu sueño junto a Theo, allá, en el irreversible Auvers-sur-Oise, 
y escarban otra tumba entre los andamiajes de la inmensa tiniebla.

Son botines de adiós, de siempre y nunca, de hambriento funeral:

se buscan en la memoria de tu muerte (Orozco, 1983: 2627).

Su sensibilidad estimulada por la obra de Van Gogh produce a su vez una nueva creación, que interpreta aquel "hipotexto" pictórico y origina un hipertexto literario. Ambos artistas han imprimido una propia idea en una materia diferente $y$ particular. El cuadro "Botines con lazos" transmite un mensaje, sin duda, y, como toda obra de arte, no se agota en esa transmisión sino que conserva una esencia que la hace significativa para múltiples recepciones e interpretaciones. Una de ellas es el poema de la poetisa argentina que nos ocupa. A la vez, nosotros hacemos del poema nuestra interpretación tratando de captar en las palabras de la poeta la recepción que ella hizo de la pintura. Y procuramos interpretar también la pintura desde nuestra propia visión.

\section{Los géneros literarios}

Los "géneros" constituyen la parte subacuática de un iceberg: para hablar de género debemos entrar en la literatura y para hablar de ella debemos entrar en el arte, el cual, naturalmente, no es un ente aislado y autónomo, sino que vive insertado en un ámbito mayor, la cultura. Dado que el arte es una de las posibles actividades humanas dentro del ámbito de la cultura es imprescindible comprender qué es cultura para poder entender qué es arte. 
Para simplificar, Spang propone volver a la antigua dicotomía de natura y cultura, definiendo natura como esa realidad que existe, aquello que nos es dado y que funciona y se desarrolla sin la intervención del hombre. El ámbito de la cultura abarca todo lo producido por la intervención del hombre. Todo lo que el hombre hace y ha hecho es fenómeno cultural. Pero en el hombre se dan los dos ámbitos: es natura que se va "aculturando": la intervención del hombre en el hombre. Lo interesante es que toda actividad y producto cultural es capaz de realizar y reunir de diversas maneras y medidas lo uno, lo verdadero, lo bueno y lo bello, es decir, los 'trascendentales'. Estos no son entes aislados, sino que se presentan y se manifiestan siempre juntos, aunque en proporciones diversas, lo que lleva a afirmar que no hay verdadera Unidad sin Verdad, Bondad y Belleza (y todas las demás posibles combinaciones). Las actividades humanas positivas son actividades culturales; $y$ son positivas cuando respetan la dignidad del hombre, ennoblecen al hombre y respetan la naturaleza en general.

El componente que más nos interesa es la modalidad, puesto que nuestro objetivo es demostrar que tanto la obra pictórica cuanto la literaria pertenecen al modo lírico. Como mencionamos en la Introducción, siguiendo a Spang, designamos 'modo' a la tradicional triada: épica, lírica y dramática; y reservamos el nombre de 'género' para referirnos a las divisiones o subdivisiones de los modos: novela, sinfonía, retrato, bajo relieve, etc. (y que otros llaman 'especies' genéricas; en definitiva, para la presente exposición, adecuamos la terminología a la teoría de base que estamos aplicando).

Los modos son la condición de la posibilidad del surgimiento de los géneros. Su tarea se limita a la canalización de la 
inspiración creativa hacia moldes particulares, hacia un género en particular. El género es una especie de molde, de uso repetido, tanto en la vida cotidiana como en el arte. Es modificable, con la única condición de que se conserven algunos rasgos importantes imprescindibles para poder reconocerlo: las constantes. Es decir que se toma en cuenta también la recepción de la obra. Como ente conceptual, el género regula la relación entre unidad u diversidad. Siempre que, a través de la repetición ordenada de elementos diversos, surge una unidad o entidad reconocible y repetible, se puede hablar de género. La pertenencia de un producto artístico a un género es uno de los aspectos definitorios fundamentales del arte y facilita la interpretación sin que estorbe a la unicidad; así pues, el género es una combinatoria flexible de constantes y variantes de varia índole.

\section{La lírica}

Nos detenemos en la lírica. En ella predomina la dimensión temporal del pasado, de la "anterioridad interiorizada", según Rafael Alvira (2001: 12), la cual presupone un trabajo de síntesis de las experiencias vividas; el sujeto aspira a apropiarse del tiempo para que este no muera, para que no se desvanezca. Se trata de una profundización reflexiva y contemplativa de las experiencias del pasado y su universalización en la obra de arte.

En el texto lírico no hay historia pero sí es ficción. El límite entre la presencia del yo y la ficción está en el proceso de síntesis de la experiencia personal elevado a experiencia universal. EI "qué" de la ficcionalización en la lírica significa que en el primer momento el poema empieza con la ficción de la situación, de la emoción o estado anímico; sigue con la creación de figuras 
líricas, representadas por pronombres personales; por último, se crea un ambiente, no con un tiempo y un espacio sino con elementos que conllevan una fuerte carga simbólica.

Si aplicamos estas consideraciones al cuadro de Vincent Van Gogh "Botines con lazos" podemos comprobar que, de hecho, en él "no pasa nada", es una naturaleza muerta. Sin embargo, se presenta densísima de vivencias y experiencias esenciales. Dice Spang que en las obras líricas de todas las artes es notoria su dimensión reducida y la insistencia en determinados matices de lo mismo (1993: 58-60). Y efectivamente, el cuadro de Van Gogh se presenta en un color único en dos o tres tonos, que van del amarillo apagado al marrón oscuro pasando por una mezcla de ambos, una especie de ocre, apreciable en la parte superior del fondo y en algunas pinceladas sobre la capellada de los botines. No hay nada más en él. Toda la fuerza lírica de la pintura está concentrada en la representación del par de botines gastados, gastadísimos, usados hasta tal punto que ya están deformados y con la puntera de la suela despegada. Quien los contempla no puede dejar de percibir la soledad y la fatiga de la vida del hombre que calzó esos botines. Y esa sintonía entre un observador del siglo XXI con el pintor de 1886 demuestra una universalidad de las emociones plasmadas, de una superación indudable de la experiencia personal convertida ahora en total, vivenciable por cualquier otro sujeto de cualquier otro espacio y tiempo. El cansancio silencioso, el agotamiento desesperanzado, el sufrimiento en soledad de un largo camino recorrido que finalmente llega a su término; sí, ahora pueden descansar, pero el descanso significa el fin, la soledad definitiva, el abandono, la muerte. Sin embargo, no es un cuadro triste, es un cuadro conmovedor, que induce a pensar, a reflexionar. Sugiere también nostalgia, porque tal vez no fue una vida mala, puede haber sido una vida 
intensa, de trabajo sí, de andar caminos sí, pero quizá no mala, de modo que se puede imaginar una vida aventurera, pero sobre todo vivida intensamente, sufrida, 'sentida' intensamente.

La obra es una forma sensible de lo real al mismo tiempo que un símbolo concreto de la espiritualidad de Van Gogh, para quien la realidad no es un mero pretexto para expresar un estado de ánimo sino que significa un reflejo del propio yo. Tal vez, por esto el artista trabaja casi exclusivamente en relación con las cosas, lo cierto, lo real, porque sabe que el mundo externo, bajo una luz y color especiales, es el equivalente afectivo de su mundo interior.

\section{Los componentes genéricos}

A la manera de las capas de una cebolla, pueden ir observándose los componentes que permiten establecer la pertenencia de una obra a determinado modo y género. Spang (2001: 166) propone siete ámbitos jerarquizados de mayor a menor por nivel de abstracción para ser aplicados a los géneros literarios y a todos los géneros artísticos: en $1^{\circ}$ nivel, la cultura; en $2^{\circ}$ nivel, el arte; en $3^{\circ}$ nivel, la literatura; en $4^{\circ}$ nivel, los modos; en $5^{\circ}$ nivel, los géneros propiamente dichos; en $6^{\circ}$ nivel, los componentes genéricos $y$ sus elementos (componente de denominación, de modo, de tema y contenido, instrumental, estructural, lingüístico-enunciativo, funcional); en $7^{\circ}$ nivel, los subgéneros (ya abandonamos aquí la abstracción) y en el $8^{\circ}$ nivel encontramos las obras concretas, con grado 0 de abstracción y la máxima objetualidad. 
Veamos los que son reconocibles en las obras propuestas en este trabajo. Sabemos que, en la mayoría de los casos, los autores no dan información genérica; en otros sí, y puede llegar a ser muy contundente, como cuando el autor declara "Comedia" o "Soneto". Este componente de denominación anticipa ya un contenido y una estructura previsible, aunque no rígida. En los casos que nos ocupan, nuestros autores no lo mencionan, pero los críticos de Van Gogh hablan de "naturaleza muerta" en el caso del cuadro "Botines con lazos" y ello nos anticipa que se trata de objetos inanimados. Lo son, en efecto; solo están allí, a la vista del observador para que el receptor contemple, medite y reflexione; son sugeridores de ideas. En el caso del poema de Olga Orozco, tampoco hay denominación genérica, pero está el hecho de que integra un libro de poemas (paratexto) y ello nos conduce al segundo componente, el modal. Es evidente la "actitud" lírica, un deseo de apropiarse de un tiempo pasado, y de interiorizar esa anterioridad. El componente de tema y contenido también responde a esta intencionalidad: el título nos lo está especificando y al saber que el poema hablará de "'Botines con lazos' de Vincent Van Gogh" no podemos esperar un comentario crítico de la pintura sino una reflexión íntima sobre lo que expresa, sobre el mensaje y su interpretación, obviamente porque lo vemos escrito en versos. Dato que nos remite al siguiente componente, el tipográfico, que es relevante en el caso de la poesía. No son versos de igual medida ni rima tradicional; por el contrario, la poetisa juega con largos versos que van desde el endecasílabo hasta las 25 y más sílabas, alternados esporádicamente con versos de 7 y 8 sílabas, pero conservando un ritmo y una música interna que acompaña la emoción del pensamiento y la reflexión sobre los diferentes avatares de la vida de Vincent Van Gogh y su 
proyección en las obras más originales, sugeridos en los detalles de los viejos botines representados en la tela:

Son tus viejos botines, infortunado Vincent, hechos a la medida de un abismo interior, como las ortopedias del exilio;

[...]

Botines de trinchera, inermes en la batalla del vendaval y el alma:

han girado contigo en todas las vorágines del cielo

y han caído en la trampa de tu hoguera oculta bajo el incendio de los campos,

sin encontrar jamás una salida,

[...]

El elemento macroestructural más importante en el texto lírico es la recreación de un estado anímico y en este caso aparece representado como un tema con variaciones, ya que acumula en las distintas estrofas variados matices del mismo tema: la soledad y la locura del poeta proyectadas en sus numerosas telas.

En cuanto al componente instrumental, podemos observar que, en la pintura, el artista trabaja con pinceladas gruesas y cortas, como si el pincel estuviera más pesado de lo normal por la cantidad y la densidad de la pintura, espesa, apenas diluida. Como dijimos antes, el color es más bien monótono, con pocas variaciones de tonalidades. Igual que en el poema de Olga Orozco, lo instrumental y lo estructural están en función del tema y contenido: expresar lo más fielmente posible un sentimiento de cansancio, de agotamiento, de camino llegado a su término en una vida de soledad y alucinaciones, y en la concreción de ese sentimiento en un objeto fiel a la realidad, 
se logra la perfecta posesión del recuerdo, de lo anteriormente vivido y ahora evocado.

En cuanto al componente lingüístico-enunciativo, el poema es extenso y presenta una primera estrofa con tres preguntas retóricas que introducen al receptor en el tema. Siguen cinco estrofas de siete, diez, siete, ocho y cinco versos respectivamente en que la voz poética le habla a un "tú", "infortunado Vincent", una segunda persona singular que hace más íntima la comunicación, que crea la sensación de que cada uno de nosotros-receptores está contemplando los famosos botines y hablando al artista:

Son tus viejos botines, infortunado Vincent,

[...]

Pero son tus botines, [...]

Fieles como tu silla, tus ojos y tu Biblia.

Aferrados a ti [...]

[...]

... han girado contigo en todas las vorágines del cielo

$[\ldots]$

ahora husmean la manta de hiedra que recubre tu sueño junto a Theo,

$[\ldots]$

\section{Conclusión}

Hemos tratado de aplicar los conceptos de componentes genéricos a una obra de arte de diferente ámbito de la literatura. Para los estudiosos de las letras, resulta natural pensar en obras dramáticas, líricas o épicas refiriéndonos a textos escritos, a obras literarias. No parece tan natural referirse de esa manera a obras de otras artes: pintura, música, 
danza, escultura. Pero nos parece que es totalmente aplicable la teoría y sumamente útil para el análisis, la comprensión y la interpretación de cualquier obra de arte: constituye un proceso receptor enriquecedor, además de poner en evidencia la íntima relación de las distintas artes entre sí, traspasando los umbrales definitorios de cada una.

La pertenencia al modo lírico de las obras de arte elegidas para su consideración en este trabajo nos parece haber sido evidenciada. Si lo lírico se debe entender como soledad contemplativa y reconfortante, una manera de escuchar hacia adentro y también de consentir y sintonizar con el otro y lo otro, creemos que esta condición fundamental se cumple en el cuadro de Van Gogh y en el poema de Olga Orozco. Ambos creadores han logrado en el proceso de creación la combinación eficaz de los recursos artísticos y como resultado una forma apropiada al tema propuesto. Todos los componentes aparecen perfectamente integrados, en tal proporción y armonía que realizan los indispensables trascendentales de la unidad, la verdad y la bondad logrando sin duda la belleza.

En el cuadro de Van Gogh, a pesar de su apego a la realidad, esto es, de reflejar el objeto con marcado realismo, se percibe una mirada mucho más profunda, más honda sobre esa realidad objetual y es esa mirada esencial la que trasciende lo fáctico y lo anecdótico para convertir esta obra en un exponente lírico, manifestación de una emoción y un sentimiento compatible en dimensión universal. En este sentido el proceso de ficcionalización ha sido plenamente realizado por ambos artistas, sea en la pintura o en el poema. Ambos han alcanzado una verdad esencial y universal que se ha expresado con incuestionable belleza. 


\section{Bibliografía}

ALVIRA, Rafael, "Los modos como dimensiones antropológicas". En: SPANG, K. (ed.) Actas del coloquio internacional 'Los géneros en las artes'. Pamplona: Universidad de Navarra, 2001: pp. 11-16.

SPANG, Kurt, "Repensando la literatura como arte (Ensayo sobre una definición de la literatura)”. En: Revista de Literatura. Tomo LXVII. Nro. 133 (2005): pp. 5-30.

SPANG, Kurt, "Modos y géneros en Literatura". En: SPANG, K. (ed.) Actas del coloquio internacional 'Los géneros en las artes'. Pamplona: Universidad de Navarra, 2001: pp. 165-176.

SPANG, Kurt, Géneros literarios. Madrid: Editorial Síntesis, 1993.

GNISCI, Armando (ed.), Introducción a la literatura comparada. Barcelona: Editorial Crítica, 2002.

PANTINI, Emilia, "La literatura y las demás artes". En: GNISCI, Armando (ed.), Introducción a la literatura comparada. Barcelona: Editorial Crítica, 2002: pp. 215-240.

VICENTE-YAGÜE JARA, María Isabel de, "La literatura y las artes en los estudios de los comparatistas europeos. Un recorrido histórico por la disciplina de la Literatura Comparada". En: Cuaderno Internacional de Estudios Humanísticos y Literatura: CIEHL. Vol. 20 (2013): pp. 33-44.

María Troiano: Profesora y Licenciada en Letras y Especialista en Educación Superior por la Universidad Nacional de Cuyo. Es miembro del Centro de Literatura Comparada de la UNCuyo y fue titular de la cátedra de Literatura Italiana en la Facultad de Filosofía y Letras de esa universidad hasta 2019. Sus líneas de investigación se enmarcan en la Traductología, particularmente la Traducción Literaria, y en la Autotraducción poética en autores italianos. Estudió la obra de las poetisas Francesca LoBue, Grazia Fresu y Anna Fresu. Fue editora del libro Cuentos para un año de Luigi Pirandello, en el que ofrece su traducción al español de 31 cuentos de Novelle per un anno con estudio introductorio y notas referidas a los criterios de traducción. También se encuentra en proceso de traducción del español al italiano del libro Del Etna al Aconcagua. Memorias de un inmigrante, de Alfio Camarda. 